\title{
Genital Ulcers in Women with HIV Proposed Revision on Management Algoritm
}

\author{
Moerbono Mochtar ${ }^{1}$, Alamanda Murasmita ${ }^{1}$, M. Eko Irawanto ${ }^{1}$, Endra Yustin Elistasari ${ }^{2}$ \\ ${ }^{1}$ Department of Dermatovenereology, Faculty of Medicine, Sebelas Maret University, Surakarta, Indonesia \\ ${ }^{2}$ Department of Dermatovenereology, Faculty of Medicine, Dr. Moewardi’s General Hospital, Surakarta, Indonesia
}

Email address:

dottalamanda@gmail.com (A. Murasmita)

To cite this article:

Moerbono Mochtar, Alamanda Murasmita, M. Eko Irawanto, Endra Yustin Elistasari. Genital Ulcers in Women with HIV Proposed Revision on Management Algoritm. American Journal of Life Sciences. Vol. 5, No. 3, 2017, pp. 93-96. doi: 10.11648/j.ajls.20170503.13

Received: March 22, 2017; Accepted: April 13, 2017; Published: June 1, 2017

\begin{abstract}
More than 100,000 people has been infected by HIV (Human Immunodeficiency Virus) in Indonesia. Mucocutaneous disorders occur in most patients with HIV during the course of the disease, it is caused by acquired immunodeficiency or the effects of the HIV therapy. One of the most important clinical manifestations is genital ulcers. A specific attention is needed to identify the clinical manifestations of genital ulcers in HIV patients to find the etiology so that the treatment of the case can be more appropriate. There are 4 cases of genital ulcers in women with AIDS (Acquired Immune Deficiency Syndrome). Both VDRL test (Venereal Disease Reseach Laboratory) and TPHA (Trepenoma pallidum Haemagglutination) test gave negative results. Two cases has successful therapy with acyclovir $400 \mathrm{mg}$ three times for 2 weeks. Test results for herpes simplex antibodies is 2 positive. The incidence of genital ulcers, especially in the chronic form, increases along with the incidence of the growing AIDS epidemic. A prospective study in Paris shows that the most common cause of genital ulcers in patients with AIDS is syphilis. All of these four cases have negative results of VDRL and TPHA, so it is necessary to consider another diagnosis as the cause of genital ulcers in immunocompromised patients that often give atypical clinical symptoms. The accuracy of the diagnosis is necessary to provide adequate treatment, especially in immunocompromised patient.
\end{abstract}

Keywords: Genital Ulcers, HIV, AIDS

\section{Introduction}

The prevalence of HIV (Human Immunodeficiency Virus) infection is reported to be increasing worldwide. Statistical data in Indonesia through 2014 shows that there are more than 100,000 HIV patients. [1], [2] Mucocutaneous disorders occur in most cases of HIV during the course of diseases including genital ulcers. [3] Genital ulcer has become a dilemmatic case. Accurate diagnosis of genital ulcers are often not easily determined by only a history taking and physical examination. Genital ulcers are also associated with the multi-etiological factors that can be found in HIV patient which masking the early symptoms of ulcers and sometimes not responding to different therapeutic modalities making it hard for a healthcare provider for determining optimal regiment of treatment. [4]

Genital ulcers in patient with HIV are often associated with syphilis, chancroid, and genital herpes. Some data provide variation of different etiologies. Management algorithm of genital ulcer issued by WHO (World Health Organization) and adapted by Brazil stated that in the case which history of vesicular lesions or clinically vesicular lesion is absent, patients were treated with genital ulcers caused by syphilis or chancroid. [5] Management guidelines of sexually transmitted disease issued by the Ministry of Health of the Republic of Indonesia in 2011 provide similar algorithms, it can give an 'open space' for a delay of genital ulcer therapy in HIV patients with HSV-2 infection which is atypical due to lack of clear guideline for the determining diagnosis and treatment. [6]

In this paper, author reported four cases of genital ulcer without a history and physical examination that shows vesicles in patient with HIV. The purpose of writing this case report is to provide broader insight, mainly to provide appropriate treatment for genital ulcer cases in people with HIV. 


\section{Cases}

Case 1.

46 years old woman admitted to the Internal Medicine Department ward in Dr. Moewardi Hospital diagnosed with AIDS Acquired Immune Deficiency Syndrome (AIDS). The patient were consulted to the Dermatovenereology Department with a large ulceration in genital area. Patient didn't notice since when the ulcer had emerged, patients complained about stinging and itching sensation without any presence of vesicle. Last sexual contact was 3 years before admitted to the hospital. Patient regularly took antiretroviral drugs given from the hospital. Physical examination result in multiple ulcer with various sizes, erythema, and visible dirty pustules. Tzank test result is negative. This patient were treated with syndrome based approach, ie $100 \mathrm{mg}$ doxycycline twice a day while waiting for the results of VDRL (Venereal Disease Reseach Laboratory) test and TPHA (Trepenoma pallidum Haemagglutination) test. Both VDRL and TPHA results were negative, the ulcers heal poorly, and patient died of bronchopneumonia.

Case 2.

53 year old woman were consulted from VCT (Voluntary Counseling and Testing) clinic to Dermatovenereology Department with complaints of pain sensation in the genital area. Patients complain of pain less than 7 days before consulted, and did not complain of having vesicle. No fever and swelling in the groin were complained. Patients had never given medication to the ulcer, she was taking lamivudine $^{\circledR} 150 \mathrm{mg}$ twice a day, zidovudine ${ }^{\circledR} 300 \mathrm{mg}$ twice a day, and nevirapin ${ }^{\circledR} 200 \mathrm{mg}$ twice a day. Physical examination of the genital region resulted in multiple form of ulceration, shallow, clearly demarcated and uneven edge, no vesicle were found. Tzank test result was negative. Gram staining examination resulted 3-5 polymorphonuclear per high field power field and $>100$ rod-shaped Gram-negative per high power field. Topical therapy for ulcer treatment were given mupirocin cream, this patient was treated as syphilis patient, given an oral antibiotic doxycycline $100 \mathrm{mg}$ twice a day for 7 days. VDRL and TPHA test gave negative results. Patients did not come back to the hospital.

Case 3.

46 year old woman came to Dermatovenereology outpatient clinic of Dr. Moewardi General Hospital with chief complain of ulceration in the pubic area since two days before admission. Patient also complain about pain and burning sensation on the ulceration. Patient denied any history of similar complain on sexual partner or history of previous vesicle. Patients deny the presence of fever. Physical examination on minor labia region resulted in multipel ulcers, various sizes, well demarcated, regular edges, erythema tissue basis. Gram staining examination resulted 2-3 polymorphonuclear per high power field and 3-5 rod-shaped Gram-positive per high power field. Patient was treated with the syndrome approach as chanchroid. Patient was given azithromycin 1 gram. Both VDRL and TPHA test results were negative. After two weeks, patient showed no significant improvement, so the patient was given acyclovir $400 \mathrm{mg}$ three times a day for two weeks and ofloxacin 400 mg twice a day for 2 weeks, patient showed a significant clinical improvement.

Case 4.

30 years old woman came to dermatovenerology clinic with a chief complain of wound around her vagina, since 4 months ago she felt some itch, and small wound without other symptoms. She went to primary health care but the lesions still exists. Patients denied any similar lesion or her sexual partner or history of the same illness. Physical examination showed multiple indurated ulcers $(12 \times 20 \mathrm{~cm})$, in erythematous base, and uneven granulated lesion. Gram staining results 20-30 polymorphonuclear cells / high power field, coccus gram positive 10-20 / high power fields. Patient was given doxicylin 2 x $100 \mathrm{mg}$ for 3 weeks and showed slow improvement, the VDRL was perfomed and the result was negative. The antibody for HSV-2 was positive.

\section{Discussion}

Genital ulcers can be caused by various infectious and non-infectious etiology. Diagnosis is based on history, physical examination, and supportive examination. Genital ulcers caused by syphilis is usually marked by painless, well demarcated, solitary ulceration with clean base. Ulcers caused by chanchroid marked by painful ulcer, brittle base and serpigenous edge, while genital ulcers caused by HSV-2 commonly marked by multiple vesicles that rupture spontaneously, sometimes painful, along with prodromal symptoms in $20 \%$ patient. [7] In all four cases with HIV positive, it is hard to get the results of anamnesis which leads to specific etiologic factors, this may be due to lack of attention from the patients, inadequate education from health professionals. Physical examination results in all three cases: multiple ulcer in genital area, pus on top, uneven edges, with various sizes. Supporting examination as an initial screening is VDRL and TPHA tests with treatment that is based on the syndrome approach which is antibiotic doxycycline $100 \mathrm{mg}$ a day for 1 month, and azithromycin 1 gram. VDRL and TPHA test results were negative in all four cases.

Two of the four cases had not achieve a successful and adequate treatment until final follow up. Two cases achieved long-term clinical improvement so that additional laboratory examination of HSV-2 immunoglobulin were conducted, and the result were positive. These patients were given acyclovir therapy 3 x $400 \mathrm{mg}$ for 2 weeks and maximum results were achieved.

It is commonly seen nowadays cases of genital ulcer in conjunction with HIV infection. Genital ulcer in conjunction with HIV infection often give an atypical appearance and the treatment approaches which only based on syndrome approach sometimes lead to unsuccessful treatment. [8] In developing countries with limited facilities, treatment of genital ulcer sometimes does not deliver optimal results, a more specific approach is needed in which the pattern of local infection from a disease should be identified, as well as 
identification of other individual factors so that the algorithm of management of genital ulcer can be done. Genital ulcers due to HSV-2 is often undiagnosed, susceptible to treatment delay, whereas the lesion may progress to extensive ulceration and the deeper tissues within a week, so that an immediate therapy is required to suppress population that can potentially transmit HIV infection through their mucosal lesion. [9]

Eichmann and Lautenschlager [10] conducted research on cases of genital ulcers for 4 years, from 170 patients, 86 patients $(51 \%)$ showed an atypical morphology of the genital lesions. The most common atypical features found in this case is deep and isolated ulcer. In 2 patients who were diagnosed with HIV, this isolated ulcer tend to have irregular diameters, more necrotic, extensive and persist for several weeks. Due to the clinical appearance of genital ulcers that tend to overlap by syphilis, chanchroid, and genital herpes, clinical diagnosis can only be made with logical reasons and may only be applied to a small amount of patients. Especially in the case that still unclear, the clinician should conduct laboratory examinations.

The relationship between HSV-2 and HIV has been widely documented, the majority of patients with HIV, both women and men in various parts of the world, have been proven infected with HSV-2. Studies of Nagot et al. reported by Lawrence Corey [11] emphasizes the need for screening and therapeutic intervention for subclinical HSV-2 infection in patients with HIV. Research with larger scale may help clinicians and health authorities in determining the need for "preventive" therapy policy, or HSV-2 test in the case of genital ulcers in HIV patients. Suppressive antiviral therapy such as acyclovir can be offered to patients who had recovered from genital ulcers, particularly in patients with CD4 cell counts less than $200 \times 10^{6} / \mathrm{L}$, because recurrence is more common in this group of patients. [12]

Preliminary research by Nijhawan et al. by randomized controlled trial (RCT) in patients with HIV and HSV-2 who were receiving highly active antiretroviral therapy (HAART) showed, suppressive therapy with acyclovir significantly reduced the release of HSV in the genital tract which asymptomatic, [13] Delany et al. conducted the research which resulted HIV-1 in plasma and genital tract is significantly reduced with the administration of suppressive therapy for HSV. [14]

In vitro, acyclovir inhibit replication of HIV-1, Lingappa et al. in 2010 reported an RCT studies involving $>1000$ subjects, stated that acyclovir reduces the risk of progression of HIV infection (16\%), lower mortality and declining in their CD4 counts. Acyclovir is well-tolerated, have low side effects and does not require specific monitoring for toxicity, [15] so in authors opinion it is advisable to give acyclovir therapy in patients with genital ulcer in areas where there are minimal laboratory facilities, isolated, and lack of health professionals, which will provide two advantages: minimize the risk of genital ulcers and reduce the progression of HIV infection.

The important factor observed by Posavad et al. is that
HAART decreased the frequency of symptomatic herpetic lesions, but does not reduce the number of HSV release in genital. Clinicians should give more attention to patients with HIV infection who received HAART. [16]

\section{Conclusion}

The incidence of genital ulcer caused by type 2 herpes in HIV positive patients has been reported to vary between 11$50 \%$, however more than $80 \%$ of these patients were asymptomatic. [17] Like other etiologies-syphilis and chanchroid-HSV-2 is important in the transmission of HIV because of damage to genital mucosa that causes inflammation and ulcers which facilitate the entry of the HIV virus. Mucosal in female genital tract have different environment, so a holistic approach on genital ulcer therapy is needed, the biggest challenge for clinicians is to diagnose genital ulcers in HIV positive patients with limited supporting facilities. Center for Disease Control and Prevention (CDC) in 2015 stated that genital ulcer treatment with antivirals can be provided with an adequate basis without waiting for the results of supporting / laboratorium examinations were completed because of the success of therapy depends on the first initial therapeutic. [18]

Indonesia is currently facing the threat of HIV and AIDS epidemic, certain sub-population survey of HIV prevalence has consistently exceeded $5 \%$, it makes Indonesia into a concentrated epidemic level, [19] we propose a revision of the guidelines for the management of sexually transmitted infections issued by Ministry of Health to incorporate antiviral therapy and antibiotic therapy in all HIV patients with genital ulcer, so that patient with HIV get a better quality life, as well as the AIDS response towards the new paradigm of zero infection, zero AIDS-related death, and zero discrimination, can be achieved.

\section{References}

[1] Maartens G, Celum C, Lewin SR. HIV infection: epidemiology, pathogenesis, treatment, and prevention. The Lancet. 2014; 384(9939): 258-71.

[2] Situasi dan analisis AIDS. [online]. 2014. [cited on $15 \mathrm{Mei}$ 2015]; Download link on: http://www.depkes.go.id/folder/view/01/structure-publikasipusdatin-info-datin.html.

[3] Oninla OA. Mucocutaneous Manifestations of HIV and the Correlation with WHO Clinical Staging in a Tertiary Hospital in Nigeria. AIDS research and treatment. 2014; 2014: 360970.

[4] Marfatia YS, Menon DS, Jose S, Patel BJ. Nonhealing genital ulcers in AIDS: A diagnostic dilemma. Indian J Sex Transm Dis. 2016 Jul-Dec; 37 (2): 197-200.

[5] Gomes Naveca F, Sabido M, Amaral Pires de Almeida T, Araujo Veras E, Contreras Mejia Mdel C, Galban E, dkk. Etiology of genital ulcer disease in a sexually transmitted infection reference center in Manaus, Brazilian Amazon. PloS one. 2013 ; 8 (5): e63953. 
[6] Hastuti EB, Nugrahini N, Subronto Y, Dzoerban Z, Djauzi S, Hastuti EY, dkk. Situasi Epidemi dan Program Penanggulangan HIV/AIDS di Indonesia. Pedoman Nasional Tatalaksana Klinis Infeksi HIV dan Terapi Antiretroviral pada orang dewasa. Kementerian Kesehatan Republik Indonesia Direktorat Jenderal Pengendalian Penyakit dan Penyehatan Lingkungan 2011.2011. p: 1.

[7] Roett MA, Mayor MT, Uduhiri KA. Diagnosis and management of genital ulcers. American family physician. 2012; 85 (3): 254-61.

[8] Aditama TY, Subuh M, Daili SF, Indriatmi W, Zubier F, Nilasari H, dkk. Pedoman Nasional Penanganan Infeksi Menular Seksual 2011. Kementerian Kesehatan Republik Indonesia Direktorat Jenderal Pengendalian Penyakit dan Penyehatan Lingkungan 2011. 2011. p: 29.

[9] Herpes Genital pada Imunokompromais. Lumintang $\mathrm{H}$, Nilasari H, Indriatmi W, Zubier F, Daili SF. Penyunting. Penatalaksanaan Infeksi Herpes Virus Humanus di Indonesia 2011. Airlangga University Press. 2011. p: 23.

[10] Stephan Lautenschlager AE. the heterogenous clinical spectrum of genital herpes. Dermatology. 2001; 202: 211-9.

[11] Corey L. Synergistic copathogens-hiv-1 and hsv-2. The New England journal of medicine. 2007; 356(8): 854-5.

[12] B H B Van Benthem JS, J A R van den hoek, J Merks, R A Coutinho, M Prins. Prevalence and risk factors of hsv-1 and hsv-2 antibodies in european HIV infected women. Sexually transmitted infections. 2001; 77: 120-4.

[13] Nijhawan AE, Delong AK, Chapman S, Rana A, Kurpewski J, Ingersoll $\mathrm{J}$, dkk. Effect of HSV-2 suppressive therapy on genital tract HIV-1 RNA shedding among women on HAART: a pilot randomized controlled trial. Infectious diseases in obstetrics and gynecology. 2012; 2012: 868526.

[14] Delany S, Mlaba N, Clayton T, Akpomiemie G, Capovilla A, Legoff J, dkk. Impact of aciclovir on genital and plasma HIV1 RNA in HSV-2/HIV-1 co-infected women: a randomized placebo-controlled trial in South Africa. Aids. 2009; 23 (4): 461-9.

[15] Lingappa JR, Baeten JM, Wald A, Hughes JP, Thomas KK, Mujugira A, dkk. Daily acyclovir for HIV-1 disease progression in people dually infected with HIV-1 and herpes simplex virus type 2: a randomized placebo-controlled trial. Lancet. 2010; 375: 824-31.

[16] Posavad CM WA, Kuntz S, Huang ML, Selke S, Krantz ZE. dkk. Frequent reactivation of HSV among HIV-1 infected treated with highly active antiretroviral therapy. Journal of Investigative Dermatology. 2004; 190: 693-6.

[17] Reis Machado J, da Silva MV, Cavellani CL, dos Reis MA, Monteiro ML, Teixeira Vde P, dkk. Mucosal immunity in the female genital tract, HIV/AIDS. BioMed research international. 2014; 2014: 350195.

[18] Disease Characterized by Genital, anal or perianal ulcers [online]. 2015. [Cited 10 Juni 2015]; Download link on: http://www.cdc.gov/std/tg2015/genital-ulcers.html.

[19] Infeksi HIV \& AIDS di Indonesia Tahapan Infeksi, Perawatan, Dukungan dan Prinsip Pengobatan. Dalam HIV \& AIDS Pendekatan Biologi Molekular, Klinis dan Sosial. Bab 33. Jusuf Barakbah, Soewandojo E, Suharto, Hadi U, Astuti WD. Penyunting. Airlangga University Press. 2007. p: 266. 